\title{
Refiguring Historical Consciousness
}

"Culturally orienting the way people live by interpreting experiences of the past is a creative, active human endeavor," writes historian and cultural theorist Jörn Rüsen. In line with this view, by way of conclusion I shall examine the relationship between historical films and theories of historical culture. At the heart of my discussion is the thesis that appropriation of histospheres in spectators' reception has a refigurative effect on our historical consciousness. This thesis extends Benjamin's theory that film "cinematographically revises the everyday"2 to our day-to-day engagement with history. On this view, the historical experiences generated by films augment the conceptions of history we have acquired from written accounts and sources with a physical-sensory dimension. ${ }^{3}$

Rüsen defines historical consciousness as a productive activity that constructs conceptions of history as an "experience of the past" through a "symbolizing appropriation of the world." 4 The core of this process is "the mental practice of narrating," which reveals the way in which historical thinking interprets the experience of time. ${ }^{5}$ Although this may appear to be a language-centered process, it also includes "pre- and metalinguistic elements such as feelings or mental images." As multi-immersive, empathy-guided experiential fields, historical films are directly relevant to these theoretical reflections. In historical films, historical experience is constituted out of a living, sensuous, synesthetic encounter with an audiovisually configured historical world. By making the past present in this way, "history" becomes a key cultural factor that enables the production

(C) The Author(s) 2021

R. Greiner, Cinematic Histospheres, https://doi.org/10.1007/978-3-030-70590-9_9 
of meaning in the here-and-now. This study has primarily considered how these sorts of specifically filmic experiences of history could be theoretically grounded and has developed an account based around the notion of the histosphere, which models divergent historical worlds out of audiovisual figurations. The term "figuration" refers not just to the arrangement and ordering of a film's individual audiovisual elements in time, but also to the "incarnation" of a cinematic body with which we empathize, so that we are thereby able to illusorily experience the film's historical world. In our perception, we assemble the disparate elements of the film into a historical world that we experience not just with our bodies/senses but also as a discursive system.

Of particular significance for the filmic figuration of historical worlds is histospheres' referential structure. The world spaces simulated by a film are constructed segments of presupposed historical worlds, which we augment with our historico-cultural world knowledge. The mise-en-histoire, which referentializes the filmic world's audiovisual figurations in popular historical consciousness, does not, however, merely draw on our individual conceptions of history, but also influences those conceptions. Thus, while the mise-en-scène organizes the filmic world created by the performative act of staging, and makes this world and act experientially available to spectators, the mise-en-histoire establishes a reciprocal relation to collective and individual conceptions of the historical past. A synthesis of artistically arranged modeling, embodied film experience, and mise-en-histoire both refreshes the content of our historical consciousness and refigures its formal structure. According to Paul Ricœur,

the narrative function, taken in its full scope, covering the developments from the epic to the modern novel, as well as those running from legends to critical history, is ultimately to be defined by its ambition to refigure our historical condition and thereby to raise it to the level of historical consciousness. ${ }^{7}$

This remark is based on the thesis

that the unique way in which history responds to the aporias of the phenomenology of time consists in the elaboration of a third time-properly historical time-which mediates between lived time and cosmic time. ${ }^{8}$ 
Ricœur's "historical time" is an experienced time that stands in relation both to the subject's biography and to historical references. Below, I interpret the historical film as a valid modern expression and agent of historical time. If historical consciousness is understood as a constellation of factors such as layers of coding, figures or types of meaning-making, interlinkages of temporal levels, perceptual and interpretive operations, and modes of processing, then the historical film represents a synthesis of these factors. ${ }^{9}$ The historical worlds constructed by films are coded as manifestations of social memory that we can explore in the mode of personalized experience. A film's histosphere connects the depiction of the past to our understanding of the present and expectations of the future. Perceptual and interpretive operations are interfused and mediated by strategies for generating embodied experience, immersion, and empathy. By bringing the past to life and making it present, a histosphere shifts our historical consciousness toward processes of physical and emotional involvement. Retrospective observation is replaced by the impression of a vivisection of history, an operation on a living organism.

One key factor for this kind of transformation of historical culture through media is the interplay between historical consciousness and memory. As a means for situating oneself relative to the world and other people, memory is a "source of the self" necessary for the formation of identity and subjectivity. Historical consciousness functions as "a culturally shaped state of this source." 10 It attaches to "the productive character of memory" and expands it by "systematic acquisition of historical experience" and "systematic application of reflective interpretive schemas." 11 This interdependence between historical consciousness and memory can be summed up in the words of Rüsen:

The powers of memory disclose the living character of historical consciousness, while the temporal horizons of historical consciousness, and their unfolding into different dimensions of perception, interpretation, and orientation, make it possible to address the experiential depth and latitude of various mental domains and activities of memory and remembering. ${ }^{12}$

This kind of interplay between historical consciousness and memory is also manifested in historical films. Immersive perception of histospheres produces prosthetic memories: media-induced memories that we recall as embodied experiences. These prosthetic memories are linked to our historical consciousness through the process of the mise-en-histoire and 
embedded in a historical context. The resultant prosthetic postmemories $^{13}$ - artificially generated historical experiences-are thus likewise a product of the interplay between memory and historical consciousness. As recollections of historical experiences produced by films, prosthetic postmemories represent a new form of historical appropriation. If we understand history as a construction of the present, as an interpretive appropriation of the past, it stands in opposition to memory. Or, as Rüsen puts it, "while memory makes or keeps the past present, history places it at the remove of a temporal difference." 14 Historical films do both: By constructing a historical world, they transform episodes of the past into present events. At the same time, they historicize the anachronistic experience attained in this manner and connect it to our historical consciousness, thereby changing it from within. This potential is based on a combination of two modes of remembering that is specific to film. Rüsen observes that memory can be "involuntary and responsive" or "deliberate and constructive." 15 The reminiscence triggers integrated in the audiovisual design of a historical film prompt spontaneous or "unbidden" memories that come to us contingently and are essentially receptive. This process of remembering is unconscious, and our response to the stimuli is primarily physical. The mise-en-histoire's referentialization, by contrast, is a productive act of remembering. By means of associative references, the world of a histosphere is embedded in our conceptions of history. Together, these two forms of memory make a substantial contribution to transforming our historical culture. The parameters of a cinematic-historical way of thinking - a combination of physical-sensory experience and associative reflection-are irrevocably inscribed into our historical consciousness, keeping it open and alive. ${ }^{16}$

\section{Notes}

1. Jörn Rüsen, Historik: Theorie der Geschichtswissenschaft, Cologne 2013, p. 223.

2. Christian Schulte, "Laboratorium Film. Krise, Technik und neue Physis bei Walter Benjamin," in: Maske und Kothurn. Internationale Beiträge zur Theater-, Film- und Medienwissenschaft. vol. 60, Göttingen 2014, p. 66.

3 . Robert Burgoyne argues that this sort of ontological shift in our historical consciousness is indeed taking place. He attributes the wave of historical films since the mid-1990s to a rising demand for sensuous historical experiences. See Robert Burgoyne, Film Nation: Hollywood Looks at U.S. History, Minneapolis 1997, p. 105. 
4. Jörn Rüsen, "Einleitung: Geschichtsbewusstsein thematisieren - Problemlagen und Analysestrategien," in Jörn Rüsen(ed.), Geschichtsbewusstsein:Psychologische Grundlagen, Entwicklungskonzepte, empirische Befunde, Cologne 2001, p. 7 (hereinafter Rüsen 2001).

5. Ibid., p. 9.

6. Ibid., p. 8.

7. Paul Ricœur, Time and Narrative, vol. 3, Chicago and London 1985, p. 102.

8. Ibid., p. 99.

9. For a breakdown of historical consciousness into permutations of individual factors, see Rüsen (2001, p. 2); see also Bodo von Borries and Andreas Körber, "Jugendliches Geschichtsbewusstsein im zeitgeschichtlichen Prozess - Konstanz und Wandel," in Rüsen 2001, pp. 317-404.

10. Rüsen (2001, p. 7).

11. Rüsen $(2013$, p. 232).

12. Rüsen (2001, p. 5).

13. See on this point the section "Prosthetic postmemory."

14. Rüsen (2013, p. 225).

15. Ibid., p. 230. Rüsen elaborates: "In summary, the two modes [of memory] can also be contrasted as follows: One mode, the receptive, harnesses the power of the unconscious; the other, the productive, sets against it the power of enlightenment. The former is prereflective [unvordenklich], the other reflective [nachdenklich]. The two modes of memory are, of course, closely interwoven; neither can be conceived without the other. Together, they make up what we can call the 'form' [Gestaltung] of the culture of memory; for 'form' [Gestalt] is both a prior impression and the result of an activity." Ibid., p. 231.

16. To empirically measure the refiguring effects of historical films on our historical consciousness, further studies with a focus on the spectator would be needed, like the qualitative interviews conducted by Andreas Sommer. According to Sommer, the findings of his study show that "historical fiction films" are "constituents of our conceptions of history that deserve to be taken seriously." He concludes "that the perspective on and evaluation of a historical event given by a film can also be adopted by the spectator." Andreas Sommer, Geschichtsbilder und Spielfilme: Eine qualitative Studie zur Kobärenz zwischen Geschichtsbild und historischem Spielfilm bei Geschichtsstudierenden, Berlin 2010, p. 257.

\section{BIBLIOGRAPHY}

Bodo von Borries and Andreas Körber, "Jugendliches Geschichtsbewusstsein im zeitgeschichtlichen Prozess - Konstanz und Wandel," in Jörn Rüsen (ed.), Geschichtsbewusstsein: Psychologische Grundlagen, Entwicklungskonzepte, empirische Befunde, Cologne 2001, pp. 317-404. 
Robert Burgoyne, Film Nation: Hollywood Looks at U.S. History, Minneapolis 1997. Paul Ricour, Time and Narrative, vol. 3, Chicago and London 1985.

Jörn Rüsen, Historik: Theorie der Geschichtswissenschaft, Cologne 2013. Jörn Rüsen, Zerbrechende Zeit: Über den Sinn der Geschichte, Cologne 2001.

Christian Schulte, "Laboratorium Film. Krise, Technik und neue Physis bei Walter Benjamin," in: Maske und Kothurn. Internationale Beiträge zur Theater-, Filmund Medienwissenschaft. vol. 60, Göttingen 2014, pp. 60-84.

Andreas Sommer, Geschichtsbilder und Spielfilme: Eine qualitative Studie zur Kobärenz zwischen Geschichtsbild und historischem Spielfilm bei Geschichtsstudierenden, Berlin 2010.

Open Access This chapter is licensed under the terms of the Creative Commons Attribution 4.0 International License (http://creativecommons.org/licenses/ by $/ 4.0 /$ ), which permits use, sharing, adaptation, distribution and reproduction in any medium or format, as long as you give appropriate credit to the original author(s) and the source, provide a link to the Creative Commons licence and indicate if changes were made.

The images or other third party material in this chapter are included in the chapter's Creative Commons licence, unless indicated otherwise in a credit line to the material. If material is not included in the chapter's Creative Commons licence and your intended use is not permitted by statutory regulation or exceeds the permitted use, you will need to obtain permission directly from the copyright holder. 